\title{
Aerobic Mesophilic, Coliform, Escherichia coli, and Staphylococcus aureus Counts of Raw Meat from the Formal and Informal Meat Sectors in South Africa
}

\author{
Ishmael Festus Jaja $^{1, *(D)}$, Ezekiel Green ${ }^{2}$ (D) and Voster Muchenje ${ }^{1}$ \\ 1 Department of Livestock and Pasture Science, University of Fort Hare, Alice 5700, South Africa; \\ vmuchenje@ufh.ac.za \\ 2 Department of Biotechnology and Food Science, Faculty of Science, University of Johannesburg, \\ Doornfontein 2028, South Africa; Egreen@uj.ac.za \\ * Correspondence: ijaja@ufh.ac.za; Tel.: +27-78-549-2098; Fax: +27-86-770-6869
}

Received: 18 March 2018; Accepted: 19 April 2018; Published: 21 April 2018

\begin{abstract}
Foodborne disease (FBD) is a global public health concern, and foods from animal sources have been associated with outbreaks of food-related illness. In this study, animal carcasses from the two abattoirs (HT1 and HT2) in the formal meat sector (FMS) and slaughter points in the informal meat sector (INMS) were examined at two stages of slaughter (before washing and after washing) for aerobic colony counts (ACC) and total viable count (TCC), as well as Escherichia coli and Staphylococcus aureus count. At each stage, carcasses were sampled by swabbing at the neck, brisket, flank, and rump. ACC for beef, mutton, and pork carcasses at HT1 and HT2 before washing were between 2.5-5.8, 2.2-4.7, and 2.7-3.7 mean $\log \mathrm{CFU} / \mathrm{cm}^{2}$, respectively, and TCC count before washing was highest on the neck of cattle $(6.3 \pm 2.4)$ and after washing was highest on the perineal of sheep $(5.7 \pm 6.9)$. In the INMS, TCC count was highest on the brisket $(6.9 \pm 3.2)$ and in the neck $(5.5 \pm 2.4)$. Higher ACC values of 6.2-6.7 mean $\log \mathrm{CFU} / \mathrm{cm}^{2}$ were obtained in the INMS. The highest count for E. coli (4.2 mean $\log \mathrm{CFU} / \mathrm{cm}^{2}$ ) after washing was in the neck, while the highest count for S. aureus (4.0 mean $\log \mathrm{CFU} / \mathrm{cm}^{2}$ ) was in the flank. All bacteria count in the INMS exceeded acceptable limits, and washing did not significantly reduce microbial load in meat in the FMS and INMS. Bacteria count in the FMS and INMS exceeded acceptable standards. However, meat processed in the INMS poses a more significant risk of FBD to consumers.
\end{abstract}

Keywords: abattoir; Escherichia coli; food safety; meat; South Africa

\section{Introduction}

Meat is a staple commodity in South Africa, consumed at a rate of $41.0 \mathrm{~kg}$ per capita per year. The nutritional composition of meat includes protein, fat, vitamins, and minerals such as iron, zinc, and phosphorus. Despite these benefits, meat has been well-known as a potential channel for spreading food-borne diseases due to its high water activity, high protein content, and approximately neutral $\mathrm{pH}$, which create favourable conditions for the multiplication and survival of bacteria [1-6].

Although muscles of healthy animals do not contain microorganisms, meat tissues get contaminated during the various stages of slaughter and transportation. The risk of contamination happens from the point of entry of animals into the slaughters up to the time of meat consumption. In this regard, the abattoir environments and slaughter processes play leading roles in the spreading of microbial contamination $[7,8]$. Many factors may contribute as sources of contamination of carcasses along the chain of slaughter, including the animal's skin and dung, equipment such as machines and cutting tools, an unhygienic environment, non-compliance with proper slaughter processes, and a lack of personal hygiene [8]. 
Escherichia coli and Staphylococcus aureus are among many common bacteria found to compromise meat quality. Many E. coli strains have emerged as important zoonotic foodborne pathogens. [9]. Hence, due to their ability to cause numerous sporadic cases and foodborne disease outbreaks in humans, they have become a significant public health threat [10-12]. Staphylococcus aureus, on the other hand, produces a variety of potent staphylococcal enterotoxins (SEs), which are resistant to inactivation by gastrointestinal proteases and are consequently responsible for staphylococcal food poisoning $[10,13]$. Severe gastroenteritis can develop within one to seven hours after the consumption of Staphylococcus aureus contaminated food, leading to diarrhoea, vomiting, and dehydration. Infections of the skin, soft tissue, joint, bone, respiratory, and endovascular disorders have frequently been reported [14]. Further complications such as pneumonia, meningitis, osteomyelitis, and toxic shock syndrome have been associated with staphylococcal infection [15].

In many developing countries, foodborne diseases (FDs) remain serious public health problems [12,16]. In South Africa, meat processed in the formal sector undergoes various checks for microbial quality. However, meat supplied from the informal sector is nonetheless not checked. The situation presents an opportunity for the supply of poor quality and contaminated meat products, enhancing the possibility of FD outbreak. A recent study indicates a high level of microbial contamination of beef carcasses at a high throughput abattoir in South Africa [17]. However, research about the quality of meat in the informal meat sector is limited. Thus, there is a need to determine the microbial quality of meat sold in the informal market. Hence, this study aims to assess the aerobic bacteria, coliform, Escherichia coli, and Staphylococcus aureus counts of raw meat, in the formal and informal meat sector.

\section{Materials and Methods}

\subsection{Sample Collection}

A convenient sampling procedure was carried out using the simple random sampling method. The convenient method allowed sampling units to be selected at random based on the number of animals slaughtered on sampling days. All samples were collected between July and November 2015 from two high through-put abattoirs (HT1 and HT2) in the formal meat sector (FMS) and five animal slaughter points in the informal meat sector (INMS) (Figure 1). A total of 400 swabbed samples were collected using a sterile cotton throat swab from the HT1 (40 cattle) and HT2 (40 sheep and 20 pigs). In total, 112 swab samples were collected from the informal meat sector (15 cattle and 13 sheep). Four parts of each animal were sampled for cattle (rump, flank, brisket, and neck), sheep (perineum, flank, brisket, and neck), and pig (ham, back, belly, and jowl) [18,19]. A swab sample of the carcasses was performed after animal stunning, skinning, and evisceration. Swabbing was done before and after washing of the carcass. All swab samples were transported to the laboratory in a cooler box stocked with ice packs and processed within 3-8 h after collection. 


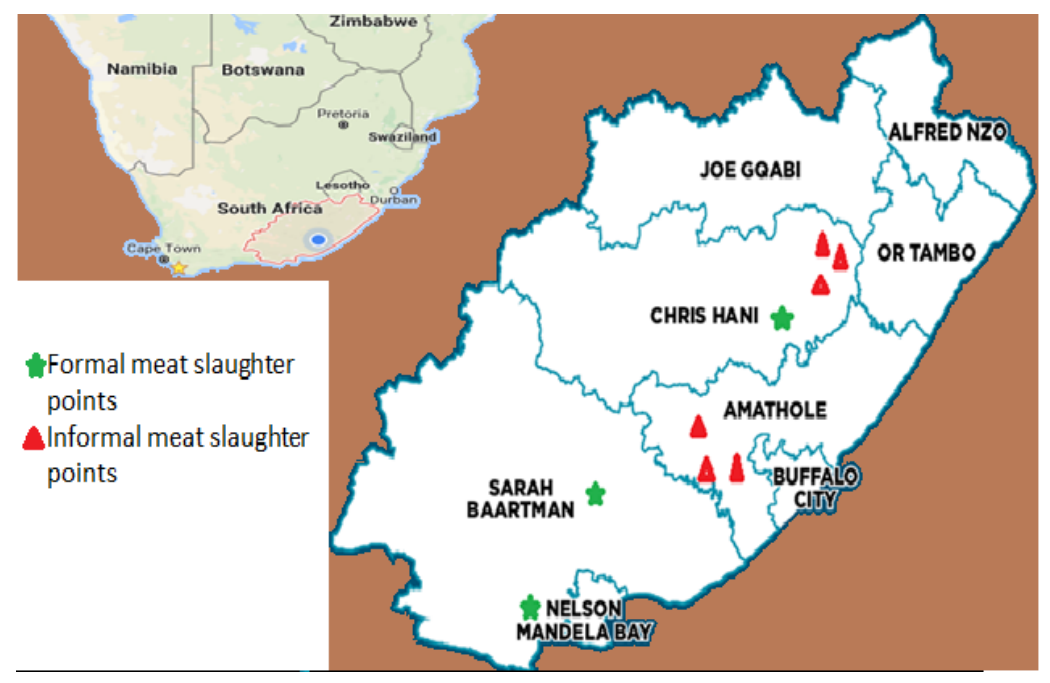

Figure 1. Map of the Eastern Cape Province showing sampling points.

\subsection{Isolation and Identification of Organisms}

Cotton throat swabs were replaced in sterile test tubes containing $0.8 \%$ saline solution, and vortexed for $2 \mathrm{~min}[19,20]$. Serial decimal dilutions of the resultant suspension were prepared and $1 \mathrm{~mL}$ of each dilution was seeded in duplicate using the pour plate method onto dishes containing MacConkey agar (MCA) and plate count agar (PCA) (Oxoid) for coliform and total viable count, respectively, and incubated at $30^{\circ} \mathrm{C}$ for $24-48 \mathrm{~h}$ [10]. Escherichia coli enumeration was repeated on Eosin methylene blue agar (Oxoid, Basingstoke, UK) by plating an appropriate dilution on plates followed by aerobic incubation at $37^{\circ} \mathrm{C}$ for $24 \mathrm{~h}$. After incubation, E. coli were counted as colonies with a distinct green metallic sheen [21,22]. For the counting and identification of $S$. aureus, $1 \mathrm{~mL}$ of diluent was seeded in duplicate using the pour plate method onto dishes containing a Mannitol salt agar plate (Oxoid) and incubated at $37^{\circ} \mathrm{C}$ for $24 \mathrm{~h}$. The microbial organisms that show a characteristic colony morphology of S. aureus on Mannitol salt agar (MSA) (Biolab, Midrand, South Africa) as a yellow coloured sheen were confirmed to be $S$. aureus. Mannitol fermentation and salt tolerance properties of $S$. aureus produced the typical yellow colonies because of the change in the $\mathrm{pH}$ [23]. Further identification of S. aureus was done using the Gram staining method, and standard biochemical assays such as oxidase and catalase tests. Gram staining was used to ascertain that there were no other airborne bacterial contaminants by confirming the characteristic morphology of $S$. aureus. Presumptive isolates of E. coli and S. aureus were stored in $20 \%$ glycerol stock pending further use.

All bacteria counts were done according to the standard prescribed by ISO 4833 and ISO 21528-2, and the result of bacteria enumeration was benchmarked with the South African standard for the microbiological monitoring of meat, process hygiene, and cleaning (VPN 15) (NDVQPH, 2010). As per VPN 15, aerobic plate counts are (i) acceptable (a): if counts are $\leq 3162 \mathrm{CFU} / \mathrm{cm}^{2}$ (3.5 log); (ii) marginal (m): if counts are $\leq 100,000 \mathrm{cfu} / \mathrm{cm}^{2}(5.0 \mathrm{log})$; and (iii) unacceptable $(\mathrm{u})$ : if counts are $>100,000 \mathrm{cfu} / \mathrm{cm}^{2}$ (5.0 log). The VPN 15 regulation for E. coli count are as follows: (i) acceptable (a): if counts are $\leq 1 \mathrm{CFU} / \mathrm{cm}^{2}(0 \mathrm{log})$; (ii) marginal (m): if counts are $\leq 10 \mathrm{CFU} / \mathrm{cm}^{2}(1 \mathrm{log})$; and (iii) unacceptable (u): if counts are $>10 \mathrm{CFU} / \mathrm{cm}^{2}(1 \mathrm{log})$ [24]. The VPN 15 document did not specify any limits to total coliform count (TCC) and Staphylococcus aureus count; hence the limits set for ACC and E. coli were adopted for TCC and Staphylococcus aureus, respectively.

\subsection{Bacterial DNA Extraction}

All isolates previously stored in glycerol stocks were resuscitated by inoculation into nutrient broth (Merck, Johannesburg, South Africa), and incubated at $37^{\circ} \mathrm{C}$ for $24 \mathrm{~h}$. The extraction of DNA was performed using a boiling method as previously described elsewhere [25]. Briefly, about three to 
five colonies were picked with the aid of a sterile wire loop and put into sterile DNAase/RNAase-free Eppendorf tubes (Biologix, Lenexa, KS, USA) containing $200 \mu \mathrm{L}$ nuclease-free water (Thermo Scientific, Waltham, MA, USA). Each suspension was mixed using a vortex machine (Digisystem Laboratory, New Taipei, Taiwan), and the cells were lysed by heating for $15 \mathrm{~min}$ in a heater block (Lasec, Cape Town, South Africa) at $100{ }^{\circ} \mathrm{C}$. The lysate was then centrifuged at $13,000 \mathrm{rpm}$ for $5 \mathrm{~min}$, and the supernatant was collected in a sterile Eppendorf tube and stored at $-20{ }^{\circ} \mathrm{C}$ for further use.

\subsection{Molecular Identification of S. aureus and E. coli Isolates}

A standard polymerase chain reaction (PCR) for species-specific thermonuclease (Nuc) gene amplification was performed to detect $S$. aureus strains from the samples, and UidA was used for detecting E. coli. Isolates were confirmed to be positive for $S$. aureus if they were defined as Gram-positive, catalase-positive cocci showing a positive PCR result for the Nuc gene, which is highly specific for S. aureus [26]. A confirmatory PCR mix was in a total volume of $25 \mu \mathrm{L}$ containing $5.0 \mu \mathrm{L}$ of the DNA template, $5.5 \mu \mathrm{L}$ nuclease-free water, $12.5 \mu \mathrm{L}$ master mix, $1.0 \mu \mathrm{L}$ forward primer, and $1.0 \mu \mathrm{L}$ reverse primer. Escherichia coli (ATCC 25922) and Staphylococcus aureus (ATCC 25923) served as the positive control strains in each test protocol [25,27-29]. The PCR conditions for Escherichia coli and Staphylococcus aureus are listed in Table 1.

All reactions were carried out in a MyCyclerTM Thermal Cycler PCR system (BioRad, Hercules, CA, USA). The PCR products $(5 \mu \mathrm{L})$ were subjected to $1.5 \%$ agarose gel electrophoresis (Separations, South Africa) stained with $0.001 \mu \mathrm{g} / \mathrm{mL}$ ethidium bromide (Sigma-Aldrich, St. Louis, MO, USA) using $0.5 \times$ Tris-borate EDTA (TBE) buffer at $100 \mathrm{~V}$ for $60 \mathrm{~min}$. The gel was visualized under the UV transilluminator (Alliance 4.7, UVItec, Cambridge, UK). A 100 bp DNA ladder (Promega, Madison, WI, USA) was used as the molecular size standard for expected band size.

\subsection{Statistical Analysis}

All data analysis was performed using Microsoft ${ }^{\circledR}$ Excel version 2007, (Microsoft, Redmond, WA, USA) mathematical functions and Statistical Package for Social Sciences (SPSS) version 22 (SPSS Inc., Chicago, IL, USA). Descriptive statistics were used to express the mean log, and standard deviation of the E. coli counts from the neck, brisket, flank, and rump of carcasses, before and after washing with water. A paired sample $t$-test was used to determine the difference in means before and after washing, and a value of $p<0.05$ was considered significant.

\subsection{Ethical Approval}

Ethical clearance number MUC351SJAJ01 was obtained from the University of Fort Hare ethics committee before the commencement of sample collection, and approval to collect samples from the abattoirs was also obtained from the abattoirs.

\section{Results}

\subsection{Aerobic Colony Counts and Total Coliform Count}

A marginal decrease was observed for aerobic colony counts (ACC), total coliform count (TCC), and E. coli and Staphylococcal count after carcass washing in the HT1 and HT2. However, notwithstanding carcass washing in HT1, ACC for jowl increased by 0.8 mean $\log \mathrm{CFU} / \mathrm{cm}^{2}$ (Table 2). The enumeration of ACC before carcass washing at HT1 ranged from 2.5 to 5.8 mean $\log \mathrm{CFU} / \mathrm{cm}^{2}$; after washing, the count ranged from 2.1 to $4.3 \mathrm{CFU} / \mathrm{cm}^{2}$. Similarly, a negligible decrease in ACC from 6.2-6.7 to 5.1-5.2 mean $\log C F U / \mathrm{cm}^{2}$ was observed in the informal sector after carcass washing (Table 3). The TCC before carcass washing in the formal meat sector (FMS) ranged from 5.0 to 6.3 mean $\log \mathrm{CFU} / \mathrm{cm}^{2}$, whereas after washing, the counts ranged from 4.6 to $6.3 \mathrm{CFU} / \mathrm{cm}^{2}$. 
Table 1. Primers and PCR conditions for molecular identification of S. aureus.

\begin{tabular}{|c|c|c|c|c|}
\hline Gene & Sequence & $\begin{array}{l}\text { Product Size } \\
\quad(b p)\end{array}$ & PCR Conditions & References \\
\hline Nuc gene & $\begin{array}{l}\text { F 5'-GCGATTGATGGTGATACGGTT-3' } \\
\text { R 5'-AGCCAAGCCTTGAACGAACTAAAGC-3' }\end{array}$ & 270 & $\begin{array}{l}\text { Initial denaturation at } 95^{\circ} \mathrm{C} \text { for } 5 \text { min was followed by } 37 \text { cycles of amplification } \\
\text { (denaturation at } 95^{\circ} \mathrm{C} \text { for } 30 \mathrm{~s} \text {, annealing at } 55^{\circ} \mathrm{C} \text { for } 30 \mathrm{~s} \text {, and extension at } 72^{\circ} \mathrm{C} \text { for } \\
60 \mathrm{~s} \text { ) and ending with a final extension at } 72^{\circ} \mathrm{C} \text { for } 10 \mathrm{~min} \text {. }\end{array}$ & {$[27,28]$} \\
\hline UidA gene & $\begin{array}{l}\text { F 5'AAAACGGCAAGAAAAAGCAG-3' } \\
\text { R 5 5'ACGCGTGGTTAACAGTCTTGCG-3' }^{\prime}\end{array}$ & 147 & $\begin{array}{l}\text { Initial denaturation at } 94^{\circ} \mathrm{C} \text { for } 2 \mathrm{~min} \text { followed by } 25 \text { cycles of denaturation at } 94{ }^{\circ} \mathrm{C} \text { for } \\
1 \mathrm{~min} \text {, annealing at } 58^{\circ} \mathrm{C} \text { for } 1 \mathrm{~min} \text {, and extension at } 72^{\circ} \mathrm{C} \text { for } 1 \mathrm{~min} \text {, and ended with a } \\
\text { final extension at } 72^{\circ} \mathrm{C} \text { for } 2 \mathrm{~min} \text {. Holding was at } 4{ }^{\circ} \mathrm{C} \text {. }\end{array}$ & [29] \\
\hline
\end{tabular}

Table 2. The logarithm 10 of mean total bacterial counts for cattle meat samples from selected abattoirs in the Eastern Cape Province, South Africa.

\begin{tabular}{|c|c|c|c|c|c|c|c|c|c|c|c|}
\hline \multirow[t]{3}{*}{$\begin{array}{l}\text { Meat } \\
\text { Sector }\end{array}$} & \multirow[t]{3}{*}{ Specie } & \multirow[t]{3}{*}{$\begin{array}{l}\text { Sampling } \\
\text { Point }\end{array}$} & \multirow{3}{*}{$\begin{array}{c}\begin{array}{c}\text { Number of } \\
\text { Carcasses }\end{array} \\
n\end{array}$} & \multicolumn{8}{|c|}{$\log _{10}$ Mean Total Bacterial Counts \pm SD $\left(\log _{10} \mathrm{cfu} / \mathrm{cm}^{2}\right)$} \\
\hline & & & & \multicolumn{2}{|l|}{ ACC } & \multicolumn{2}{|l|}{ TCC } & \multicolumn{2}{|c|}{ E. coli } & \multicolumn{2}{|c|}{ S. aureus } \\
\hline & & & & BW & AW & BW & AW & BW & AW & BW & AW \\
\hline \multirow[t]{4}{*}{ HT1 } & cattle & Rump & 40 & $4.2 \pm 2.2$ & $2.7 \pm 1.6$ & $5.0 \pm 2.1$ & $4.6 \pm 2.5$ & $4.1 \pm 2.1$ & $3.2 \pm 2.0$ & $3.9 \pm 2.4$ & $3.2 \pm 2.4$ \\
\hline & & Flank & 40 & $2.5 \pm 1.5$ & $2.1 \pm 1.3$ & $4.1 \pm 2.4$ & $3.8 \pm 2.5$ & $3.6 \pm 2.8$ & $2.9 \pm 1.9$ & $4.2 \pm 2.6$ & $3.8 \pm 2.4$ \\
\hline & & Brisket & 40 & $2.7 \pm 1.5$ & $2.6 \pm 1.3$ & $4.3 \pm 2.7$ & $4.3 \pm 2.7$ & $3.7 \pm 2.2$ & $3.3 \pm 1.9$ & $3.7 \pm 2.2$ & $2.8 \pm 1.8$ \\
\hline & & Neck & 40 & $5.8 \pm 2.6$ & $4.3 \pm 2.5$ & $6.3 \pm 2.4$ & $5.4 \pm 3.1$ & $5.0 \pm 2.7$ & $4.2 \pm 2.6$ & $3.9 \pm 2.3$ & $3.6 \pm 2.3$ \\
\hline \multirow[t]{8}{*}{ HT2 } & Sheep & Perineal & 40 & $3.2 \pm 2.4$ & $2.9 \pm 2.4$ & $4.6 \pm 2.5$ & $5.7 \pm 6.9$ & $2.8 \pm 2.6$ & $2.8 \pm 2.5$ & $4.2 \pm 2.6$ & $3.4 \pm 2.2$ \\
\hline & & Flank & 40 & $2.4 \pm 1.6$ & $2.3 \pm 1.7$ & $3.5 \pm 2.4$ & $3.5 \pm 2.3$ & $2.5 \pm 2.0$ & $2.6 \pm 1.9$ & $4.9 \pm 2.7$ & $4.0 \pm 2.5$ \\
\hline & & Brisket & 40 & $2.2 \pm 1.5$ & $2.3 \pm 1.8$ & $3.9 \pm 2.3$ & $3.6 \pm 2.2$ & $2.1 \pm 1.6$ & $2.7 \pm 2.2$ & $4.1 \pm 2.4$ & $2.9 \pm 1.7$ \\
\hline & & Neck & 40 & $4.7 \pm 2.7$ & $4.3 \pm 2.5$ & $4.5 \pm 2.6$ & $4.2 \pm 2.8$ & $3.5 \pm 2.3$ & $3.2 \pm 2.0$ & $3.9 \pm 1.9$ & $3.7 \pm 2.3$ \\
\hline & Pig & Ham & 20 & $3.6 \pm 1.8$ & $3.5 \pm 2.7$ & $4.8 \pm 2.4$ & $3.2 \pm 1.9$ & $2.5 \pm 1.5$ & $3.0 \pm 1.7$ & $3.5 \pm 1.5$ & $2.7 \pm 1.5$ \\
\hline & & Back & 20 & $2.7 \pm 1.0$ & $2.7 \pm 0.9$ & $3.1 \pm 0.9$ & $1.1 \pm 1.0$ & $3.7 \pm 2.0$ & $2.9 \pm 1.1$ & $4.3 \pm 2.3$ & $3.2 \pm 1.7$ \\
\hline & & Belly & 20 & $2.9 \pm 1.1$ & $2.7 \pm 1.5$ & $3.9 \pm 2.2$ & $3.0 \pm 1.5$ & $2.6 \pm 1.4$ & $3.6 \pm 1.6$ & $2.9 \pm 1.2$ & $3.3 \pm 1.5$ \\
\hline & & Jowl & 20 & $3.7 \pm 1.3$ & $4.5 \pm 1.9$ & $4.2 \pm 2.0$ & $2.8 \pm 2.1$ & $2.6 \pm 1.7$ & $2.7 \pm 1.1$ & $5.3 \pm 2.0$ & $3.2 \pm 1.6$ \\
\hline
\end{tabular}

HT1 and HT2: High throughput abattoirs in the formal meat sector; $n$ : Number of animals sampled; ACC: Aerobic colony count; TCC: Total coliform count; SD: Standard deviation; BW: Before washing; AW: After washing. 
Table 3. The logarithm 10 of mean total bacterial counts for cattle meat samples from selected location in the informal meat sector in the Eastern Cape Province, South Africa.

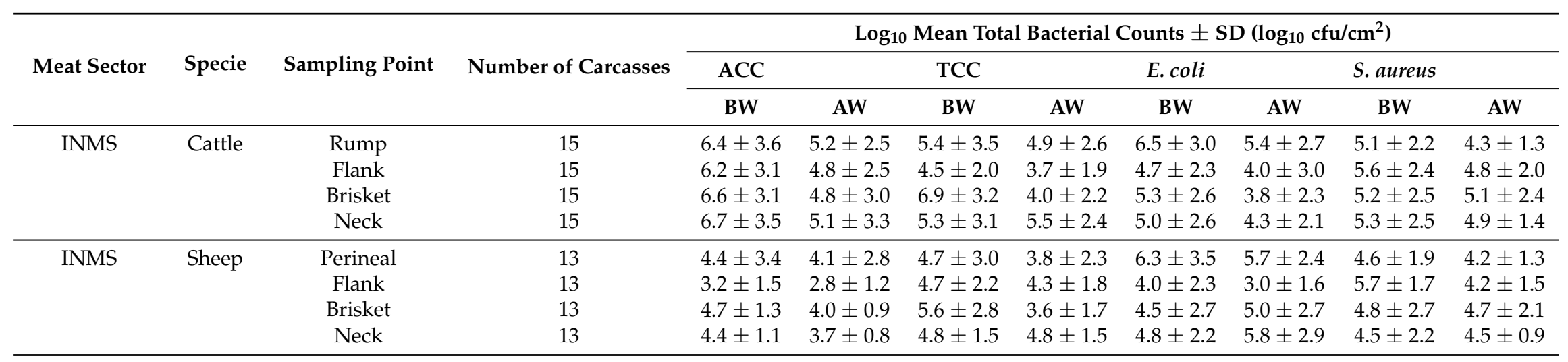

INMS: samples obtained from the informal meat sector; ACC: Aerobic colony count; TCC: Total coliform count; SD: Standard deviation; BW: Before washing; AW: After washing 
The VPN 15 regulations for aerobic plate count and total coliform count are (i) acceptable (a): if counts are $\leq 3162 \mathrm{cfu} / \mathrm{cm}^{2}$ (3.5 log); (ii) marginal (m): if counts are $\leq 100,000 \mathrm{cfu} / \mathrm{cm}^{2}(\leq 5.0 \mathrm{log})$; and (iii) unacceptable $(\mathrm{u})$ : if counts are $>100,000 \mathrm{cfu} / \mathrm{cm}^{2}(>5.0 \mathrm{log})$.

The VPN 15 regulations for E. coli count are as follows: (i) acceptable (a): if counts are $\leq 1 \mathrm{cfu} / \mathrm{cm}^{2}$ (0 log); (ii) marginal (m): if counts are $\leq 10 \mathrm{cfu} / \mathrm{cm}^{2}(1 \mathrm{log})$; and (iii) unacceptable (u): if counts are $>10 \mathrm{cfu} / \mathrm{cm}^{2}(1 \mathrm{log})$ (NDVQPH 2010).

The VPN 15 regulations for aerobic plate count and total coliform counts are: (i) acceptable (a): if counts are $\leq 3162 \mathrm{cfu} / \mathrm{cm}^{2}(3.5 \mathrm{log})$; (ii) marginal (m): if counts are $\leq 100,000 \mathrm{cfu} / \mathrm{cm}^{2}(\leq 5.0 \mathrm{log})$; and (iii) unacceptable $(\mathrm{u})$ : if counts are $>100,000 \mathrm{cfu} / \mathrm{cm}^{2}(>5.0 \mathrm{log})$.

The VPN 15 regulations for E. coli count are as follows: (i) acceptable (a): if counts are $\leq 1 \mathrm{cfu} / \mathrm{cm}^{2}$ (0 log); (ii) marginal (m): if counts are $\leq 10 \mathrm{cfu} / \mathrm{cm}^{2}(1 \mathrm{log})$; and (iii) unacceptable (u): if counts are $>10 \mathrm{cfu} / \mathrm{cm}^{2}(1 \mathrm{log})$ (NDVQPH 2010).

INMS ranged from 5.3 to 5.4 mean $\log \mathrm{CFU} / \mathrm{cm}^{2}$. However, washing led to a 0.2 mean $\log$ $\mathrm{CFU} / \mathrm{cm}^{2}$ increase in the TCC for perineum.

\section{Escherichia coli and Staphylococcus aureus Count}

Washing led to a minimal decrease in the E. coli count in cattle at HT1, except for sheep flank and briskets in HT2, where the count increase by 0.1 and 0.6 mean $\log \mathrm{CFU} / \mathrm{cm}^{2}$, respectively. Likewise, the count for pig ham and belly increased by 0.5 and 1.0 mean $\log C F U / \mathrm{cm}^{2}$, respectively (Table 2). The E. coli enumeration in the INMS was higher than the standard value for red meat and washing only minimally reduced the count in cattle. However, the count for sheep brisket and neck increased by 0.5 and 1.0 mean $\log \mathrm{CFU} / \mathrm{cm}^{2}$ after washing, respectively (Table 3). Staphylococcus aureus count for the formal meat sector (HT1 and HT2) did not significantly $(p<0.05)$ differ after carcass washing. The $S$. aureus count for pig belly increased by 0.4 mean $\log \mathrm{CFU} / \mathrm{cm}^{2}$. The $S$. aureus count in the INMS was similar to those obtained from the FMS. The molecular detection of $S$. aureus in beef, mutton, and pork carcasses at HT1 and HT2 was $16.5 \%, 15.7 \%$, and $9 \%$, respectively. Whereas $3.6 \%, 7.9 \%$, and $15 \%$ S. aureus was detected in slaughter mens' hands at HT1, HT2, and INMS, respectively (Table 4).

Table 4. Presence of S. aureus isolated from two high throughout abattoirs [HT1 $(n=194)$ and HT2 $(n=89)$ ] and informal meat sector [INMS $(n=100)]$.

\begin{tabular}{ccccc}
\hline Abattoirs & Sampling Points & Sample Size & Presumptive Isolates (\%) & Confirmed with PCR (\%) \\
\hline \multirow{2}{*}{ HT1 } & Cattle & 168 & $109(56.2)$ & $32(16.5)$ \\
& slaughtermen & 12 & $12(6.2)$ & $7(3.6)$ \\
& Door handle & 4 & $3(1.5)$ & $0(0)$ \\
& Knife & 8 & $7(3.6)$ & $5(2.6)$ \\
& Saw & 2 & $1(0.5)$ & $0(0)$ \\
& Total & 194 & $132(68)$ & $44(22.7)$ \\
\hline \multirow{2}{*}{ HT2 } & Sheep & 36 & $27(30.3)$ & $14(15.7)$ \\
& Pig & 36 & $21(23.6)$ & $8(9)$ \\
& slaughtermen & 8 & $8(9)$ & $7(7.9)$ \\
& Door handle & 2 & $1(1.1)$ & $0(0)$ \\
& Knife & 5 & $3(3.4)$ & $1(1.1)$ \\
& Saw & 2 & $0(0)$ & $30(0)$ \\
& Total & 89 & $60(67.4)$ & $16(16)$ \\
INF & Cattle & 20 & $16(16)$ & $32(32)$ \\
& Sheep & 52 & $44(44)$ & $15(15)$ \\
& Slaughter men & 16 & $15(15)$ & $5(5)$ \\
& Knife & 12 & $8(8)$ & $68(68)$ \\
\hline
\end{tabular}

HT1 and HT2: High throughput abattoir in the formal meat sector (FMS), INMS: Informal meat sector. 


\section{Discussion}

The majority of poor people in low and middle-income countries purchase meat from the informal market because the meat is cheap, and the market is often proximal to rural communities $[30,31]$. However, in the absence of meat safety standards and hygiene, the chemical composition of meat favours microbial growth to unacceptable levels. Hence, microbially contaminated meat poses the risk of transmission of foodborne diseases (FBD) to consumers. The prevalence of FBD is a growing global problem, especially in developing countries, where hygiene management systems are poorly implemented [19,32-34]. Since major gut-dwelling foodborne pathogens such as Salmonella, E. coli, Campylobacter, and other enterobacteria are excreted from the gastrointestinal tract of food-producing animals, cross-contamination is often a result of poor slaughter technique and hygiene standards at abattoirs [11,35-38]. Sampling for Microbial estimation in the rump, flank, brisket, and neck have been conducted in many countries including Namibia, Ireland, Serbia, and Switzerland [19,39-41], but to our knowledge, none have been conducted in the Eastern Cape Province, South Africa. Furthermore, the 2017-2018 outbreak of listeriosis has been linked to the contamination of meat packages, justifying the necessity of continuous sampling of various parts of carcasses, packaging, and abattoir environments.

The results for FMS show that the rump, neck, perineum, ham, and jowl were the most contaminated. However, in the INMS, contamination was not specific to any part of the carcass, as almost all parts of the carcass were contaminated. On some occasions, animal carcasses were manually pulled or push along the slaughter rail. Hence this could account for the level of contamination reported for the rump, neck, perineum, ham, and jowl. In similar studies, the brisket yielded a higher result that the neck, flank, and rump [19,42], but in another study, microbial contamination did not significantly differ for the rump, flank, brisket, and neck [43].

Washing of carcasses in the informal sector did not significantly $(p<0.05)$ decrease the level of microorganism in meat and probably contributed to further spread of the contamination of carcass. Although the bacteria enumeration in carcasses in the formal sector (FMS) yielded fewer counts when compared to those from the informal meat sector (INMS), bacterial levels, however, in many instances, exceeded the regulated benchmark [24]. For example, the TCC count at HT1 for the neck (4.6 \pm 2.5$)$ and rump $(5.4 \pm 3.1)$ mean $\log \mathrm{CFU} / \mathrm{cm}^{2}$ even after washing is worrisome. Likewise, the TCC count at $\mathrm{HT} 2$ of the perineum $\left(5.7 \pm 6.9\right.$ mean $\left.\log \mathrm{CFU} / \mathrm{cm}^{2}\right)$ after washing is concerning. Washing in these instances led to an increased microbial count in meat. Similarly, E. coli and S. aureus count in FMS and INMS exceeded acceptable limits even after washing.

The result of this study strongly suggests some basic hygiene problems along the slaughter and processing chains, as ACC, TCC, and E. coli counts are standard methods for estimating the microbial contamination of carcasses $[1,7,8,19]$. In one study of Salmonella, Escherichia coli, Enterobacteriaceae, and aerobic colony count, during beef slaughter in the Eastern Cape Province of South Africa, washing did not reduce the microbial load in the carcass [17]. Studies elsewhere reported a similar finding that washing did not reduce the microbial contamination of meat $[18,20,21]$. However, in many of the studies, a significant reduction in bacteria counts was only noted after the singeing, scalding, blasting, and chilling of meat $[17,19,20]$.

Meat from the INMS seldom undergoes blasting and chilling, which underscores the high risk of FBD associated with the consumption of such meat. The purchase and consumption of meat from such sources have further been linked to increased risk of food poisoning $[38,44,45]$. The high bacteria count detected in the meat from INMS depicts the unregulated nature of slaughter processes and marketing in the sector. The absence of refrigeration, sanitation, adequate health inspection, and risk analysis is responsible for the foodborne illness associated with the consumption of meat from the INMS [46]. Process stages such as stunning, skinning, scalding, evisceration, and chilling are sensitive points where microbial contamination of carcass can be prevented. Hence establishing a critical control point along this chain is essential $[18,36,47,48]$. 
Foodborne pathogens such as E. coli and other enterobacteria are essential causes of diarrhoeal diseases. Enteric and diarrheal diseases are important causes of childhood death in the low-and-middle-income countries; and are regarded as the second cause of death, after lower respiratory diseases in children under five years old [49-51]. The South African National Institute for Communicable Diseases (NCID) report of foodborne disease (FBD) for January to June 2017 indicated that Staphylococcus, Salmonella, and Clostridium perfringens were the leading cause of FBD in the period previously mentioned [52]. Hence, the result of the present study highlights, once more, the importance of proper cleaning and disinfection procedures in the process control at abattoirs during slaughter. It also exposes the lax in good manufacturing practice and hygiene management and critical control points (HACCP) at the slaughterhouses.

The prevalence of S. aureus in the FMS (22.7\%, and 33.7\%) and INMS (68\%) can be compared to the prevalence of $S$. aureus elsewhere [1,22,53-55]. However, a lower prevalence of $S$. aureus was reported in studies conducted in Brazil and Pakistan $[7,56]$. Staphylococcus aureus can asymptomatically survive in the skin and nasal vestibules of humans and animals. Roughly $20 \%$ of humans are considered as persistent carriers, and $30 \%$ are intermittent carriers of S. aureus in the nostrils $[33,57]$.

Many slaughter workers were observed during sample collection to be singing during slaughter, enhancing the possibility of oral to carcass contamination at such times. Hence the prevalence of S. aureus in this study would be expected because it is a principal component of the nasal vestibule and skin. Although S. aureus commensally inhabits the skin and nasal passage, it can cause widespread infections, from superficial skin infections to severe, and potentially fatal, invasive disease, including food-related illness [58]. Staphylococcal food poisoning triggered by enterotoxin-producing S. aureus is a significant foodborne disease globally [59]. In many countries, the foods that most often cause this type of food poisoning are red meat and their products [53].

It is reasonable to think that apart from cross contamination by abattoir workers, other sources of contamination could be dirty hides, abattoir environments, knives, and other cutting machines $[36,41,60,61]$. Stricter process hygiene control is necessary to improve the microbial quality of meat. The limitation of the present study would be that the study compared the microbial quality of meat in only two high throughput abattoirs and meat slaughter points in the informal market. The result obtained from the study should not be generalised for all formal abattoirs in the province. Furthermore, some selective media could hamper the multiplication of cells with sub-lethal injuries, thereby hindering their growth and ultimately affecting the counts. However, these limitations did not diminish the important finding in the study. Complete eradication of microbial contamination of meat may be very difficult to achieve, but microbial counts above an acceptable level present a problem not only to the quality and shelf life of meat but also to the consumer. Since washing did not substantially reduce the microbial load, the study buttresses the need for the adoption of pre-treatment of animal hide and skin, as well as carcasses, as practised in many countries $[19,62,63]$ and strict adherence to hygiene management and assessment system.

\section{Conclusions}

Microbial count of meat in the formal and informal meat sectors exceeded acceptable limits by South African regulation. The high ACC, TCC, E. coli, and S. aureus counts in meat from the formal and informal meat sectors not only point to the existence of contamination and a weak hygiene management system, but also highlight the high risk of consumers contracting meat-related infections if not properly cooked. Foodborne diseases remain a global public health crisis which requires multifaceted, integrated, regional, and international collaborative solutions. The problem of meat hygiene in the informal setting could be even worse given the ubiquitous and unstructured nature of the sector. Interventions aimed at educating communal farmers who are the primary suppliers of meat in the INMS, consumers, and meat handlers could lead to an improved meat hygiene culture. Moreover, the training and re-training of slaughter workers on good slaughter practices (GSPs) and a hygiene management system (HMS) are crucial. 
Acknowledgments: Authors are grateful to the National Research Foundation for providing the funding for this project through the Centre for Excellence in Food Security (Animal product safety- project grant No. 140702). We would like to thank the participating abattoirs.

Author Contributions: All authors conceived the project design of the study. Ishmael Festus Jaja was responsible for data collection, data analysis and conscripting the manuscript, Voster Muchenje and Ezekiel Green supervised the project, interpreted data results and edited the manuscript.

Conflicts of Interest: The authors declare no conflict of interest.

\section{References}

1. Angkititrakul, S.; Polpakdee, A.; Chuanchuen, R. Prevalence of Salmonella enterica, Escherichia coli and Staphylococcus aureus in Raw Meat in Thai Self-Service Style Restaurants in Khon Kaen Municipality. Thai J. Vet. Med. 2013, 43, 265-268.

2. Fayemi, P.O.; Muchenje, V. Meat in African context: From history to science. Afr. J. Biotechnol. 2012, 11, 1298-1306. [CrossRef]

3. Hagen-Zanker, J.; Morgan, J.; Meth, C. South Africa's Social Security System: Expanding Coverage of Grants and Limiting Increases in Inequality; Over-Seas Development Institute: London, UK, 2011.

4. Cawthorn, D.-M.; Steinman, H.A.; Hoffman, L.C. A high incidence of species substitution and mislabelling detected in meat products sold in South Africa. Food Control 2013, 32, 440-449. [CrossRef]

5. FAO. The State of Food and Agriculture: Livestock in the Balance (Food and Agriculture Organization of the United Nations); FAO: Rome, Italy, 2009; Available online: www.fao.org/docrep/012/i0680e/i0680e.pdf (accessed on 23 September 2016).

6. Ahmed, A.M.; Shimamoto, T. Isolation and molecular characterization of Salmonella enterica, Escherichia coli O157:H7 and Shigella spp. from meat and dairy products in Egypt. Int. J. Food Microbiol. 2014, 168-169, 57-62. [CrossRef] [PubMed]

7. Ali, N.H.; Farooqui, A.; Khan, A.; Khan, A.Y.; Kazmi, S.U. Microbial contamination of raw meat and its environment in retail shops in Karachi, Pakistan. J. Infect. Dev. Ctries. 2010, 4, 382-388.

8. Kh, H.; Boukhors, K.T.; Dahmani, A.; Zenia, S.; Aissi, M. Survey of hygiene in ovine slaughterhouses of Algiers region by bacteriological analysis of carcasses. Afr. J. Microbiol. Res. 2012, 6, 4722-4726.

9. Caine, L.-A.; Nwodo, U.U.; Okoh, A.I.; Ndip, R.N.; Green, E. Occurrence of virulence genes associated with diarrheagenic Escherichia coli isolated from raw cow's milk from two commercial dairy farms in the Eastern Cape Province, South Africa. Int. J. Environ. Res. Public Health 2014, 11, 11950-11963. [CrossRef] [PubMed]

10. Mhone, T.A.; Matope, G.; Saidi, P.T. Aerobic bacterial, coliform, Escherichia coli and Staphylococcus aureus counts of raw and processed milk from selected smallholder dairy farms of Zimbabwe. Int. J. Food Microbiol. 2011, 151, 223-228. [CrossRef] [PubMed]

11. Jindal, A.K.; Pandya, K.; Khan, I.D. Antimicrobial resistance: A public health challenge. Med. J. Armed Forces India 2015, 71, 178-181. [CrossRef] [PubMed]

12. Havelaar, A.; Martyn, D.K.; Paul, R.; Torgerson Herman, J.G.; Tine, H.; Lake, R.J.; Praet, N.; Bellinger, D.C.; de Silva, N.R.; Gargouri, N.; et al. World Health Organization Global Estimates and Regional Comparisons of the Burden of Foodborne Disease in 2010. PLoS Med. 2015, 12, 1-23. [CrossRef] [PubMed]

13. Casagrande Proietti, P.; Coppola, G.; Bietta, A.; Luisa Marenzoni, M.; Hyatt, D.R.; Coletti, M.; Passamonti, F. Characterization of genes encoding virulence determinants and toxins in Staphylococcus aureus from bovine milk in Central Italy. J. Vet. Med. Sci. 2010, 72, 1443-1448. [CrossRef] [PubMed]

14. Shuiep, E.S.; Kanbar, T.; Eissa, N.; Alber, J.; Lämmler, C.; Zschöck, M.; El Zubeir, I.E.M.; Weiss, R. Phenotypic and genotypic characterization of Staphylococcus aureus isolated from raw camel milk samples. Res. Vet. Sci. 2009, 86, 211-215. [CrossRef] [PubMed]

15. Jiamboonsri, P.; Pithayanukul, P.; Bavovada, R.; Chomnawang, M.T. The inhibitory potential of thai mango seed kernel extract against methicillin-resistant Staphylococcus aureus. Molecules 2011, 16, 6255-6270. [CrossRef] [PubMed]

16. Ahmed, A.M.; Shimamoto, T.; Shimamoto, T. Characterization of integrons and resistance genes in multidrug-resistant Salmonella enterica isolated from meat and dairy products in Egypt. Int. J. Food Microbiol. 2014, 189, 39-44. [CrossRef] [PubMed] 
17. Nyamakwere, F.; Muchenje, V.; Mushonga, B.; Makepe, M.; Mutero, G. Assessment of Salmonella, Escherichia coli, Enterobacteriaceae and aerobic colony counts contamination levels during the beef slaughter. J. Food Saf. 2016, 36, 548-556. [CrossRef]

18. Bolton, D.J.; Pearce, R.A.; Sheridan, J.J.; Blair, I.S.; McDowell, D.A.; Harrington, D. Washing and chilling as critical control points in pork slaughter hazard analysis and critical control point (HACCP) systems. J. Appl. Microbiol. 2002, 92, 893-902. [CrossRef] [PubMed]

19. Zweifel, C.; Capek, M.; Stephan, R. Microbiological contamination of cattle carcasses at different stages of slaughter in two abattoirs. Meat Sci. 2014, 98, 198-202. [CrossRef] [PubMed]

20. Wheatley, P.; Giotis, E.S.; McKevitt, A.I. Effects of slaughtering operations on carcass contamination in an Irish pork production plant. Ir. Vet. J. 2014, 67, 1. [CrossRef] [PubMed]

21. Bello, M.; Lawan, M.K.; Kwaga, J.K.P.; Raji, M.A. Assessment of carcass contamination with E. coli O157 before and after washing with water at abattoirs in Nigeria. Int. J. Food Microbiol. 2011, 150, 184-186. [CrossRef] [PubMed]

22. Ahmad, M.U.D.; Sarwar, A.; Najeeb, M.I.; Nawaz, M.; Anjum, A.A.; Ali, M.A.; Mansur, N. Assessment of microbial load of raw meat at abattoirs and retail outlets. J. Anim. Plant Sci. 2013, 23, 745-748.

23. Pathare, N.A.; Asogan, H.; Tejani, S.; Al Mahruqi, G.; Al Fakhri, S.; Zafarulla, R.; Pathare, A.V. Prevalence of methicillin resistant Staphylococcus aureus [MRSA] colonization or carriage among health-care workers. J. Infect. Public Health 2016, 9, 571-576. [CrossRef] [PubMed]

24. NDVQPH. Standard for the Microbiologival Monitoring of Meat, Process Hygiene and Cleaning; National Directorate for Veterinary Quarantine and Public Health: Pretoria, South Africa, 2010.

25. Iwu, C.J.; Iweriebor, B.C.; Obi, L.C.; Okoh, A.I. Occurrence of non-O157 Shiga toxin-producing Escherichia coli in two commercial swine farms in the Eastern Cape Province, South Africa. Comp. Immunol. Microbiol. Infect. Dis. 2016, 44, 48-53. [CrossRef] [PubMed]

26. Graber, H.U.; Pfister, S.; Burgener, P.; Boss, R.; Meylan, M.; Hummerjohann, J. Bovine Staphylococcus aureus: Diagnostic properties of specific media. Res. Vet. Sci. 2013, 95, 38-44. [CrossRef] [PubMed]

27. Rinttilä, T.; Lyra, A.; Krogius-Kurikka, L.; Palva, A. Real-time PCR analysis of enteric pathogens from fecal samples of irritable bowel syndrome subjects. Gut Pathog. 2011, 3, 6. [CrossRef] [PubMed]

28. Ali, R.; Al-Achkar, K.; Al-Mariri, A.; Safi, M. Role of Polymerase Chain Reaction (PCR) in the detection of antibiotic-resistant Staphylococcus aureus. Egypt. J. Med. Hum. Genet. 2014, 15, 293-298. [CrossRef]

29. Saxena, T.; Kaushik, P.; Krishna Mohan, M. Prevalence of E. coli O157:H7 in water sources: An overview on associated diseases, outbreaks and detection methods. Diagn. Microbiol. Infect. Dis. 2015, 82, 249-264. [CrossRef] [PubMed]

30. Oguttu, J.W.; McCrindle, C.M.E.; Makita, K.; Grace, D. Investigation of the food value chain of ready-to-eat chicken and the associated risk for staphylococcal food poisoning in Tshwane Metropole, South Africa. Food Control 2014, 45, 87-94. [CrossRef]

31. Grace, D. Food safety in low and middle income countries. Int. J. Environ. Res. Public Health 2015, 12, 10490-10507. [CrossRef] [PubMed]

32. Doulgeraki, A.I.; Ercolini, D.; Villani, F.; Nychas, G.J.E. Spoilage microbiota associated to the storage of raw meat in different conditions. Int. J. Food Microbiol. 2012, 157, 130-141. [CrossRef] [PubMed]

33. Hammad, A.M.; Watanabe, W.; Fujii, T.; Shimamoto, T. Occurrence and characteristics of methicillin-resistant and -susceptible Staphylococcus aureus and methicillin-resistant coagulase-negative staphylococci from Japanese retail ready-to-eat raw fish. Int. J. Food Microbiol. 2012, 156, 286-289. [CrossRef] [PubMed]

34. Hessain, A.M.; Al-Arfaj, A.A.; Zakri, A.M.; El-Jakee, J.K.; Al-Zogibi, O.G.; Hemeg, H.A.; Ibrahim, I.M. Molecular characterization of Escherichia coli O157:H7 recovered from meat and meat products relevant to human health in Riyadh, Saudi Arabia. Saudi J. Biol. Sci. 2015, 22, 725-729. [CrossRef] [PubMed]

35. Iwu, C.J.; Iweriebor, B.C.; Obi, L.C.; Basson, A.K.; Okoh, A.I. Multidrug-Resistant Salmonella isolates from Swine in the Eastern Cape Province, South Africa. J. Food Prot. 2016, 79, 1234-1239. [CrossRef] [PubMed]

36. Buncic, S.; Nychas, G.J.; Lee, M.R.F.; Koutsoumanis, K.; Hébraud, M.; Desvaux, M.; Chorianopoulos, N.; Bolton, D.; Blagojevic, B.; Antic, D. Microbial pathogen control in the beef chain: Recent research advances. Meat Sci. 2014, 97, 288-297. [CrossRef] [PubMed]

37. Jaja, I.F.; Mushonga, B.; Green, E.; Muchenje, V. A Quantitative Assessment of Causes of Bovine Liver Condemnation and Its Implication for Food Security in the Eastern Cape Province South Africa. Sustainability 2017, 9, 736. [CrossRef] 
38. FAO. Expert Consultation on Community-Based Veterinary Public Health Systems. Available online: http:/ / www.fao.org/docrep/016/y5405e/y5405e00.htm (accessed on 13 May 2016).

39. Nastasijevic, I.; Mitrovic, R.; Buncic, S. The occurrence of Escherichia coli O157 in/on faeces, carcasses and fresh meats from cattle. Meat Sci. 2009, 82, 101-105. [CrossRef] [PubMed]

40. Magwedere, K.; Shilangale, R.; Mbulu, R.S.; Hemberger, Y.; Hoffman, L.C.; Dziva, F. Microbiological quality and potential public health risks of export meat from springbok (Antidorcas marsupialis) in Namibia. Meat Sci. 2013, 93, 73-78. [CrossRef] [PubMed]

41. Thomas, K.M.; McCann, M.S.; Collery, M.M.; Logan, A.; Whyte, P.; McDowell, D.A.; Duffy, G. Tracking verocytotoxigenic Escherichia coli O157, O26, O111, O103 and O145 in Irish cattle. Int. J. Food Microbiol. 2012, 153, 288-296. [CrossRef] [PubMed]

42. Byrne, B.; Dunne, G.; Lyng, J.; Bolton, D.J. Microbiological carcass sampling methods to achieve compliance with 2001/471/EC and new hygiene regulations. Res. Microbiol. 2005, 156, 104-106. [CrossRef] [PubMed]

43. Zweifel, C.; Fischer, R.; Stephan, R. Microbiological contamination of pig and cattle carcasses in different small-scale Swiss abattoirs. Meat Sci. 2008, 78, 225-231. [CrossRef] [PubMed]

44. FAO. National Food Safety Systems in Africa-A Situation Analysis. FAO/WHO Reg. Conf. Food Saf. Africa 2005. Available online: www.fao.org/tempref/docrep/fao/meeting/010/j6122e.pdf (accessed on 25 Febuary 2016).

45. Uyttendaele, M.; Franz, E.; Schlüter, O. Food Safety, a Global Challenge. Int. J. Environ. Res. Public Health 2015, 13, 67. [CrossRef]

46. Fahrion, A.S.; Jamir, L.; Richa, K.; Begum, S.; Rutsa, V.; Ao, S.; Padmakumar, V.P.; Deka, R.P.; Grace, D. Food-safety hazards in the pork chain in Nagaland, north east India: Implications for human health. Int. J. Environ. Res. Public Health 2013, 11, 403-417. [CrossRef] [PubMed]

47. Thomas, M.K.; Murray, R.; Flockhart, L.; Pintar, K.; Pollari, F.; Fazil, A.; Nesbitt, A.; Marshall, B. Estimates of the Burden of Foodborne Illness in Canada for 30 Specified Pathogens and Unspecified Agents, Circa 2006. Foodborne Pathog. Dis. 2013, 10, 639-648. [CrossRef] [PubMed]

48. Qekwana, D.; McCrindle, C.; Oguttu, J.; Grace, D. Assessment of the Occupational Health and Food Safety Risks Associated with the Traditional Slaughter and Consumption of Goats in Gauteng, South Africa. Int. J. Environ. Res. Public Health 2017, 14, 420. [CrossRef] [PubMed]

49. Gohar, A.; Abdeltawab, N.F.; Fahmy, A.; Amin, M.A. Development of safe, effective and immunogenic vaccine candidate for diarrheagenic Escherichia coli main pathotypes in a mouse model. BMC Res. Notes 2016, 9, 80. [CrossRef] [PubMed]

50. Songe, M.M.; Hang'ombe, B.M.; Knight-Jones, T.J.D.; Grace, D. Antimicrobial resistant enteropathogenic Escherichia coli and Salmonella spp. in houseflies infesting fish in food markets in Zambia. Int. J. Environ. Res. Public Health 2017, 14, 21. [CrossRef] [PubMed]

51. Fischer Walker, C.L.; Sack, D.; Black, R.E. Etiology of diarrhea in older children, adolescents and adults: A systematic review. PLoS Negl. Trop. Dis. 2010, 4. [CrossRef] [PubMed]

52. NICD. Foodborne Disease Outbreaks Reported to the National Institute of Communicable Diseases. January-December 2017. Available online: www.nicd.ac.za (accessed on 5 Janurary 2018).

53. Kitai, S.; Shimizu, A.; Kawano, J.; Sato, E.; Nakano, C.; Kitagawa, H.; Fujio, K.; Matsumura, K.; Yasuda, R.; Inamoto, T. Prevalence and characterization of Staphylococcus aureus and enterotoxigenic Staphylococcus aureus in retail raw chicken meat throughout Japan. J. Vet. Med. Sci. 2005, 67, 269-274. [CrossRef] [PubMed]

54. Nel, S.; Lues, J.F.R.; Buys, E.M.; Venter, P. Bacterial populations associated with meat from the deboning room of a high throughput red meat abattoir. Meat Sci. 2004, 66, 667-674. [CrossRef]

55. Abdalrahman, L.S.; Wells, H.; Fakhr, M.K. Staphylococcus aureus is More Prevalent in Retail Beef Livers than in Pork and other Beef Cuts. Pathogens 2015, 4, 182-198. [CrossRef] [PubMed]

56. De Melo, C.B.; de Sa, M.E.P.; Sabino, V.M.; de Fatima Boechat-Fernandes, M.; Santiago, M.T.; Schwingel, F.F.; Freitas, C.; Magioli, C.A.; Cabral-Pinto, S.; McManus, C.; et al. Microbiological detection of bacteria in animal products seized in baggage of international air passengers to Brazil. Prev. Vet. Med. 2015, 118, $22-27$. [CrossRef] [PubMed]

57. Jans, C.; Merz, A.; Johler, S.; Younan, M.; Tanner, S.A.; Kaindi, D.W.M.; Wangoh, J.; Bonfoh, B.; Meile, L.; Tasara, T. East and West African milk products are reservoirs for human and livestock-associated Staphylococcus aureus. Food Microbiol. 2017, 65, 64-73. [CrossRef] [PubMed] 
58. Kadariya, J.; Smith, T.C.; Thapaliya, D. Staphylococcus aureus and staphylococcal food-borne disease: An ongoing challenge in public health. BioMed Res. Int. 2014, 2014, 827965. [CrossRef] [PubMed]

59. Stewart, G.C. Staphylococcal Food Poisoning, 3rd ed.; Elsevier Inc.: Columbia, MO, USA, 2017.

60. Hauge, S.J.; Nafstad, O.; Rotterud, O.J.; Nesbakken, T. The hygienic impact of categorisation of cattle by hide cleanliness in the abattoir. Food Control 2012, 27, 100-107. [CrossRef]

61. Yilmaz, A.; Gun, H.; Ugur, M.; Turan, N.; Yilmaz, H. Detection and frequency of VT1, VT2 and eaeA genes in Escherichia coli O157 and O157:H7 strains isolated from cattle, cattle carcasses and abattoir environment in Istanbul. Int. J. Food Microbiol. 2006, 106, 213-217. [CrossRef] [PubMed]

62. Hugas, M.; Tsigarida, E. Pros and cons of carcass decontamination: The role of the European Food Safety Authority. Meat Sci. 2008, 78, 43-52. [CrossRef] [PubMed]

63. Reid, C.-A.; Avery, S.W.; Hutchison, M.L.; Buncic, S. Evaluation of sampling methods to assess the microbiological status of cattle hides. Food Control 2002, 13, 405-410. [CrossRef]

(C) 2018 by the authors. Licensee MDPI, Basel, Switzerland. This article is an open access article distributed under the terms and conditions of the Creative Commons Attribution (CC BY) license (http://creativecommons.org/licenses/by/4.0/). 